\title{
On the current problems of education for democracy
}

\author{
Martin Strouhal
}

Abstract: The aim of the text is to formulate certain problems and dangers in relation to education for democratic citizenship. The core of these considerations points to the problem of neglecting the fundamental motive of the problem of democracy, which is the relation to truth. The text defines four problem areas that cause reductive understanding of education for democracy, namely: 1. Our understanding of democracy has been reduced to securing the distribution of power in a state and defence of freedom of speech which eliminates the contradictions in the concept of democracy and leaves only its legal-political aspects. 2. The key condition of democracy, which is respect for human rights, has become complicated by the constant proliferation of human rights, oftentimes with individual needs being confused with human rights. 3 . We have resigned upon addressing the important issue of balance between equality and outstandingness resulting in consequences for culture as well as education, i. e. loss of identity and absence of footing to base it on. 4. Democracy is closely linked to the ability to think and make decisions according to truth and not on the basis of immediate interests as democracy primarily has to do with an ideal that we look up to.

The text also tries to show that education for democracy cannot be satisfactorily ensured by development of partial competences for co-operation and diversity acknowledgement since democracy does not only consist in system and rules but ideas and relation to Truth in the first place.

Key words: competences, contradiction, democracy, diversity, education, otherness, outstandingness, school, truth

My aim in this paper is to draw attention to certain questions and dangers that we need to be aware of when discussing education for democratic citizenship. In my reflections, I consider problems that are both educational and crucial to policy-making in education but also raise issues far beyond 
the limits of didactics or education policy. I am convinced that without relying on philosophy for a thorough conceptual analysis of what we mean by democracy, our efforts will remain stuck at the half-way mark. The focus here is on the Czech curriculum; however, this approach can be applied more widely and more generally. Education for democracy is crucial because democracy is, on the one hand, under permanent challenge from various camps, and, on the other, is often mistakenly or inadequately interpreted and presented.

Democracy and education for democratic citizenship have been studied from political science, sociological and pedagogical perspectives. I will concentrate on a problem that has not been given sufficient consideration, the relationship between democracy and Truth. I will try to set out four crucial problems which render the idea of democracy hard to grasp and accept.

Maintaining democracy and freedom is key to the future of the post-totalitarian countries that emerged thirty years ago from their isolation from the West to reclaim the place where they had historically belonged. That place is Europe, which is not just a geographical formation but above all an idea, a work-in-progress of the spirit (Brunschwicg, 19471; Patočka, 2002). Now, our concern is to maintain our position in this European space, but we ought to help ensure that Europe as a whole does not become detached from its historical memory, in which the idea of democracy has pride of place.

Initially, Czech thinking on education and policy on education for democracy might seem to be fulfilling its task. We have a curriculum in which education for democratic citizenship is a "cross-cutting" theme, and we have a whole range of materials, on method and content, that are recommended for primary and secondary schools. We have a number of projects aimed at fostering critical thinking, dialogic skills, human-rights "literacy" and democratic attitudes. Nonetheless, education for democracy needs to be developed with an eye to preparing the ground - if I can put it like this, the soil that enables the seeds to germinate - and this means that the schools in which we teach the cross-cutting theme of democratic citizenship should be democratic in overall ethos and functioning. This in turn implies that the democratic principles can only be meaningfully applied if teachers are brought up and educated for democracy. The problem of education for de-

\footnotetext{
The great French philosopher Léon Brunschwicg characterised the European Spirit as "never resting": "L'esprit européen est un esprit qui ne se repose jamais." L'esprit européen, 1947, p. 183.
} 
mocracy is therefore connected with the school's profile as an institution and with training for future teachers. Teachers' informed outlook, educational level and grasp of what is essential for the establishment and maintenance of democracy are what ultimately determine the educational success of the cross-cutting theme, "education for democracy."

\section{What Does "Democracy" Mean?}

In discussions on the desirable form of the curriculum, questions are asked such as: What are the challenges facing schools teaching education for democracy today?, What sort of themes can be used to teach pupils the skill set of the democratic citizen? (Jeřábek et al., 2007)

But what does the word "democracy" mean? What challenges does it involve? Do we have a sufficiently structured understanding of the concept of democracy? And is the school in which we want to educate children for democracy itself democratic?

First and foremost, the problem of democracy cannot be addressed merely technically, as the functioning or failure of the institution or system, or using the criterion of whether the communication skills that make dialogue possible are acquired. No, it must be addressed at a much deeper level - the level of ideas and ideals - as it is here that attitudes and value orientations develop. Democracy is a way of organising life that makes it possible for individuals to enjoy maximum freedom. On the other hand, it carries within itself the permanently dangerous potential that the freedom of the individual will be removed. That occurs when democracy degenerates into an instrument of oppression by the majority, who fail to realise that it is Truth, and not just the narrow interests of those presently in power, that should decide the nature of reality (Plato, Rep. VIII, e.g. 536d-e; Hejdánek, 2012, pp. 68-69). ${ }^{2}$ If we ask whether the Czech "civic education" curriculum makes it possible to approach education for democracy in this more searching way, then the answer is "no". The Czech Framework Educational Programme for

2 One of the great Czech contemporary philosophers, Ladislav Hejdánek (2012, p. 69) wrote in one of his essays on Truth: „Truth cannot be found through voting because the majority of people may be and usually are wrong, whenever important issues are involved. Neither can Truth be found by its being entrusted to certain individuals or to a limited number of the privileged. The only way Truth can be humanly facilitated so that it can be heard and appeal is to create a public space, institutionally or semi-institutionally for an essential dialog, wherever it proves to be important as a matter of principle. However, the dialogue can only happen in a place where obstacles are not put in its way, i.e. where dignity and freedom of each individual are respected." 
primary and lower secondary schools contains a definition of democracy, sets out some of the characteristics of a democratic citizen such as attitudes, values and competences, but one essential thing is missing - it does not clarify the connection between democracy and Truth; instead that is concealed by the repeated references to the relativising concepts of diversity and otherness (Jeřábek et al., 2007, pp. 97-98). ${ }^{3}$ The same applies to Metodický portál $R V P^{4}$, which provides supporting materials on civics that do not go beyond the methodological or didactic level of the teaching situation. It is as if we are afraid to admit that democracy is not a simple phrase to be learned, but an ideal that has to be gradually internalised, personified in our own lives on the lifelong journey to democracy. We thereby risk making very serious mistakes.

A note of clarification: I base my reflections on the premise that the cultural and intellectual history of Europe is highly ambivalent but that the idea of the rule of Truth has been a recurrent dynamic within it. This idea shifted into new intellectual, terminological, and social contexts, which may be why it sometimes seems to have retreated into the background or completely disappeared. In the 20th century some thinkers, including Popper (1945), expressed a fear of the idea of the Rule of Truth claiming it had always been just a cover for totalitarian tendencies, all the more dangerous for being hidden (Foucault, 1976; Lyotard, 1979). There is some truth in the scepticism about Truth: the idea of democracy comes from the same roots as totalitarianism (see Plato, Rep. VIII, 563e15); it is simply that these roots have diverged, finding their way through different fertile soil. Plato was a humanist as well as a fierce critic of democracy, in the sense that government was based on the assumption of human equality and indifference to the idea there is a hierarchy of values (Plato, Rep. VIII, 557b11562). Hence, implicit in the Platonic grounding of the European idea of Truth is a complicated relationship between Truth, normativity and human rights or human dignity.

The history of Europe is testimony to the struggle for Truth as an ideal standing high above perspectivism, relativism and the degeneration of man. It is an ideal that is concerned with the human desire to improve; improve our understanding of our relationship to other living beings. We must not, however, forget that this ideal is pursued and realised through contradic-

\footnotetext{
3 https: / / www.google.com/url? sa $=t \& r c t=j \& q=\& e s r c=s \&$ source $=w e b \& c d=\& v e d=2 a h U$ KEwj9lqnPqOHsAhUEzhoKHYvPCTAQFjABegQIBRAC\&url=http\%3A\%2F\%2Fwww. msmt.cz\%2Ffile\%2F9481_1_1\%2F\&usg=AOvVaw38rpvj53jXx-bZxk7aD0pj

4 https://digifolio.rvp.cz/view/view.php?id=15013
} 
tions and their problematic nature, and it is in this way that it comes to permeate our understanding of our reality and ourselves. ${ }^{5}$

Likewise, the democratic ideal cannot be understood except against the background of the contradictions that it involves. The limits of Plato's ideas reflected the social situation of the period, the institution of slavery, and the true state of a Greek democracy in decline. The danger in our time, by contrast, lies in our tendency to understand the ideal of democracy technically and purely politically, that is, in a distorted way, which perverts its core. Because there are too many potential dangers and disputed aspects in today's conception of democracy, I shall limit myself here to a few that I consider fundamental:

1. Our understanding of democracy has been reduced to the components of securing the distribution of power in the state and defending freedom of speech. This eliminates the contradictions in the concept of democracy but strips it of its deeper philosophical aspects, leaving only the legalpolitical aspects.

2. The key condition of democracy, which is respect for human rights, is complicated by the constant proliferation of human rights. In some cases needs are being reformulated as rights.

3. We have given up on the attempt to address the important issue of the balance between equality and outstandingness, and can see the results of this in culture as well as in education. A school that is called a democratic school is one dominated by Otherness, without further specification so that this otherness can easily become a dictate requiring the surrender of any kind of fixed identity - with no belief allowed to claim a priority position.

4. Finally, we must emphasise ever more strongly that the question of democracy is closely linked to the ability to think and make decisions according to truth, and not on the basis of immediate interests. The question of democracy is above all the question of the ideal that we acknowledge.

\footnotetext{
The classic representative of the idea is obviously Hegel. Brunschwicg following Maine de Biran's observation formulates the non-metaphysical version: "Les obstacles de la science (et ceci est bien remarquable), les obstacles, dis-je, font partie de la science.' En effet, ils obligent la pensée à rebondir sans pourtant se modeler sur eux, inventant et exploitant les formes de combinaisons, de plus en plus paradoxales et subtiles, qui multiplie de nos jours le génie des mathématiciens pour les mettre au service de l'investigation physique." And he reminds us of Decart's words in his letter to Princess Elisabeth: "Bien que chacun de nous soit une personne séparée de des autres, et dont, par conséquence, les intérêts sont en quelque sorte distincts de ceux du reste $\mathrm{du}$ monde, on doit toutefois penser qu'on ne saurait subsister seul. Et il faut toujours préférer les intérêts du tout dont on est partie à ceux de sa personne en particulier." L'esprit européen, 1947, pp. 182-3, 185.
} 


\section{Philosophical versus legal-political concept of democracy}

I have already covered this point to some extent. There is much discussion on education for democracy, but it must first engage with the fact that democracy is not based solely on the possibility of free choice, together with the right of the majority to decide. We have to delve deeper, to ask about the majority's attitude to truth and the question of the hierarchical ordering of views and attitudes in the light of the truth, which we are (hopefully still) seeking. In other words, the issue is whether we present democracy to children in school as a mainly technical issue or a philosophical problem. It is whether we and they will look just at the functionality of the mechanisms maintaining the system of democratic institutions, or whether we will have the courage to consider - via the problem of democracy - much more difficult, as yet unanswered, questions. For example, some definitions of democracy rightly place the emphasis on the fact that it is a unique way of organising social life and, in this sense, it is not easily transferable from one society to another.

Democracy is certainly a political "order", distinguished by the characteristic division of the three powers of the state and the "rule of the majority", but a more structured approach that takes in the whole tradition of the theory of democracy tells us that it is also a modus vivendi, for which the key values concern justice, freedom and human dignity. Democracy for the authors of the Czech tradition (Masaryk, Rádl and Patočka) is above all an ideal humanising the way that we see the things around us and giving real content to the principle of respect for human beings.

Once we acknowledge that democracy is not just a particular way of arranging public affairs, we must ask how our concept of education for democracy connects with the other aspects of the democratic idea. This will inevitably lead us to a myriad of practical and above all educational questions. If democracy is to survive, and acquire deeper roots, if it is to work for more than one generation, we need to explore how we can teach children to regard democratic institutions such that they honour and protect them when they grow up. We need to ask about the real purpose of the social dialogues through which truth and justice are supposed to be pursued, and not just about the opinions of those who have won the most recent elections. After all, even people whose (perhaps covert) programme is the destruction of democracy and the enforcement of narrow interests at the expense of truth and the real interests of the majority can win a democratic victory. 
This problem is attracting more attention in Czech society in the context of disputes over the political situation, where one side is concerned only with the percentage of the vote won in democratic elections, while the other appeals to the "suprapolitical" principles against which political facts-onthe-ground should be measured, even if those facts were originally established in democratic, that is, free elections. Both points of view are of course debatable. Unfortunately, in the public debate, instead of proper analysis we more often encounter mantras, repetitions of the same old platitudes about democracy, dialogue and the need for critical thinking, legitimacy and so on. These platitudes are often associated with ingrained attitudes based on political interests or on mere sympathy or antipathy, and they prevent us from recognising that the complicated relationship between the individual, society and ideas changes from situation to situation and is inevitably the subject of lifelong reflection without the prospect of definitive conclusions. For example, the dispute over the role that should be accorded to expertise and knowledge in social dialogue cannot be resolved by simple reference to a party's electoral success (not to speak of property and economic power). This was considered by Plato's Socrates in his allegory of the helmsman (Rep. VIII, 551c); he argued that people should choose those who are experts in such matters to govern the state, just as boatmen choose the helmsman who can guide them safely through stormy waters. An uncompromising and fixed aversion or admiration for a certain figure, view or programme is never enough either. In other words - reality changes and as it does so do the ways in which we see it. To take another example, the status of all kinds of social minorities cannot be solved by simple reference to the power of the majority, but nor can it be solved by the mere assertion of the rights of individuals and members of minorities. We need to ask whether a particular minority is doing something beneficial, and for whom, as well as asking whether the human dignity of the representatives of the minority is being respected.

For reasons of self-preservation every society has to actively try to correct the influence of demagogy, populism and false interpretations of anything important. But our historical experience also offers repeated warnings, that cannot be disregarded, against the exploitation of desire to correct real or alleged social and political abuses for political power. We know that attempts to moralise the political order have led to catastrophe and inhuman behaviour on a mass scale.

If I wanted to summarise my thoughts up to this point in one sentence, I would go back to the beginning: the question of education for democracy necessarily implies the question of what we understand by the human be- 
ing and human life with its relation to Truth, which is always pursued and realised in contradictory, ambivalent situations. In this context responsibility for Truth lies with individuals, and not political parties or other groups claiming privileged positions for themselves. Furthermore, this responsibility for Truth is not something that leads us to definitive conclusions that can be dogmatically applied, but instead enables us to live in permanent openness to that which we consider true.

Democracy then is not just a legal-political concept, but a great social ideal. It assumes the existence of contradictions in the courses that we venture to follow as true and right, and at the same time it assumes our willingness to recognise the other as a being worthy of dignity, our attention, and endowed with certain rights.

\section{Human rights or human needs?6}

And here we turn to the second problem, which Milan Kundera and Jacques le Goff ${ }^{7}$ describe as the ever more widespread phenomenon of the transformation of need into right. Wherever there is a human need, we now have a tendency to talk of it being satisfied as a right. There is no longer a need for a relationship, but a right to it, just as the need to be different has become the right to be different. The concept of a right has become hypertrophied and in the process has become empty. Our obsession with turning even dubious needs into demands for rights is one reason western man is unable to define a meaningful hierarchy of values, to engage with what is and is not admissible, as well as what is and is not obligatory or fundamental. The social situation in various parts of the globalised world calls out for solutions, but these will never emerge where, for example, there is a recognised right to diversity without qualification. As Ladislav Hejdánek (2012, pp. 70-71) says: "Tolerance without awareness of the Truth as the highest criterion can lead to indifference to morality and thought or to some kind of aestheticism."

\footnotetext{
$6 \quad$ A few paragraphs in the following text were published in my essay The Foundations of Multiculturalism and Its Moral and Axiological Implications In Kwiatkowski, M.; Mielczarek-Żejmo, A.; Strouhal, M. (eds.) (2020). Multiculturalism. From Crisis to Renewal? Prague: Karolinum, pp. 57-77.

7 See Le Goff's article 'Trop de droits tuent le droit' in Ouest-France (25th September, 2003) inspired by Kundera's idea in L'immortalité that "le monde est devenu un droit de l'homme et le désir d'amour un droit à l'amour" (the world has become man's right and everything in it has become a right: the desire for love the right to love).

8 It is essential to emphasise that Hejdanek was promoting the idea of Truth as nonobjective, non-factual reality that defies identification with anything in the world: no truth that people are able to formulate in the world can be the last and the highest measure of Truth. Rather, it is a light, a criterion through the prism of which all the partial truths grasped by humans are revealed.
} 
As mentioned above, the same limits and the same misleading concept of democracy can be found in the Framework Educational Programme and the programme text of the EU Council's Competences for Democratic Culture: the question of human rights is conceptually bound to the values of diversity, individuality and respect for differences in opinion and value orientation (Jeřábek et al., 2007, pp. 97-98; Barrett, 2016). It cannot be objected to unless something essential is missing. The eight book of Plato's The Republic articulates a problem which we fall into when we understand democracy solely as an environment in which - to put it simply - everybody can think, say and do (with the exceptions defined in criminal law) whatever they like. In a democratic environment where individuals are unaware their interests and needs are also subject to the "judgement" of Truth, or rather, the thinking which shows their stances in the light of truth, there is a danger of a slipping rapidly into a form of tyranny. Nowadays, we can talk about the tyranny of a decadent public opinion, the undereducated or an insufficiently developed judgement. In such a social atmosphere, the "hypertrophied" need of the individual to enforce their momentary and limited self-image without any regard for social responsibility, or even interest in contemplating the possible forms of their own future is quite naturally but mistakenly understood as a human right.

As a result, in the above mentioned EU text identity or a personal and open relationship towards Truth is replaced with the fashionable managerial-psychological concept of "self-efficacy".

"Self-efficacy is an attitude towards the self. It involves a positive belief in one's own ability to undertake the actions that are required to achieve particular goals, and confidence that one can understand issues, select appropriate methods for accomplishing tasks, navigate obstacles successfully and make a difference in the world" (Barrett et al., 2016, p. 13).

\section{Otherness, indifference, identity}

And so considering the relationship between equality and outstandingness, we see that relativism and its declaration of the rights (and perhaps also the real social need) for diversity is therefore no longer enough. There has to be some critical reflection (not a doctrine!) on what can and cannot be tolerated within the framework of diversity and different views of the world, man and values; there has to be some thought on priorities. (see Quilliot, 1996, pp. 244-255). Diversity and cultural differences continue to be the mantras of traditional multiculturalism and what is known as the "inter- 
cultural" approach to society. Unreformed, however, these perspectives may become a source of dangerous, morally disintegrative tendencies that undermine any possibility of common humanist ideals and destroy the idea of the unity of the human race. If supporters of multiculturalism wish to avoid the hegemonisation of certain cultural types at the expense of others, they must acknowledge the need to abandon the idea that culture is an objective set of determinants of human life and destiny and instead see culture as a search for a shared human ideal that is not objective, because it is not existent. Instead it is that what ought to be (sollen in the Kantian sense).

It is unclear whether we are still capable of recognising the superior weight of expert judgements over a mere plurality of views. While in some areas we can still do this, in others (above all in aesthetic and moral) areas, we have an enormous problem with it. Alain Finkielkraut in a book of contemporary observations and social commentaries, La seule exactitude (2015), is critical of the contemporary democratic French school for "preaching the cult of the Other", while at the same time rejecting as extremely boring the "enormous mental reaching beyond the self-required to commune with the great works of the past." Instead, the school is supposed to keep up with the events of the moment and adjust the curriculum to the ordinary cultural experience of today's children. In other words: the cult of Otherness and the right to difference threaten us with a dogmatic confirmation of the banalisation of the world of culture, the decline of education and the forgetting of the truth handed down for millennia in various guises, that in being ourselves we are historical, and that our spiritual identity consists above all "in community with the dead", as Auguste Comte once put it.

Czech curricular documents including the study for the revision of the Framework Educational Programme focused on Education for Citizenship (Vávrová \& Hesová et al., 2017) talk about education for democratic citizenship above all in connection with respect for otherness, and even insert the theme of democracy into the context of multiculturalism without further clarification. Here lies the core of the problems that in Czechia we know of only second hand, but which in countries like France are among the sorest points not just of social policy but of everyday educational practice. Otherness as a value implicit in multicultural approaches requires us to consider which forms of otherness can be or need to be accepted and why, and which should not, because they potentially threaten democracy itself.

Although nowadays many try to discard the theme of identity as being old-fashioned and artificially constructed, at its core is the European iden- 
tity which is at risk. European identity, not as something that is easily defined and then passed on to learn and share, but rather as something that has its roots in the principle of reflection and the ability to have a bad conscience about one's, from a certain perspective, great deeds. In other words, if there is something like a European identity, an identity of the West, then it consists in permanent determination and the ability to critically rethink everything we have achieved and have done. If this hyperreflexivity and hypercriticalness is not to turn against itself, it must be fused with the determination to act and the willingness to take responsibility for the decisions that we consider to be better than others. ${ }^{9}$

I believe we need to think about the conditions of the possibility of a new theory of normativity, which will highlight processuality, and the changeable character of reality, and will have sustained moral force even in a period of mass laicisation in Europe. In this context, Roberto Frega (2006, p. 209) recalled Dewey's concept of the practical factor of thought. It is a concept that seems to show that insofar as the constitution of any kind of problem is concerned we must understand judgement to be a logical norm conditioned and generated by situation, experience and practice. We must, then, focus on the tasks generated by the new social situation that has been provoking us into ever greater experimentation and at the same time challenging the traditional conception of normativity. This can no longer be doctrinal in the sense of offering formalistic or merely conceptual principles, but must be based on the experiences and needs of practice. Yet how are we to deal with the relationship between theory and practice if the once clear principles of theory are increasingly complicated by the multiplicity and diversity of their practical applications and contents? The problem of thought and judgement can no longer be isolated from the problem of life, and this has fundamental implications for education. Dewey's idea about the need to link school and life is in this sense valid for us too.

\section{John Dewey's idea of democratic education}

The difficult relationship between the ideal (norm) and the reality (praxis) finally brings us to the question of the connection between democracy and

9 As early as 1971, the essay In Bluebeard's Castle: Some Notes Towards the Redefinition of Culture by Steiner was published. Steiner postulates a question in connection to the ubiquitous "calls for a repentant self-reflexion of the west" in which he, among other things, asks: "Est-il d'autres races qui se soient tournées, dans un esprit de pénitence, vers leurs anciens esclaves? D'autres civilisations qui aient désavoués, au nom de la morale, l'éclat de leur passé?" (Quoted according to the French translation, Steiner, 1990, pp. 77, 78.) 
the formation of the child's attitude to democracy on the one hand, and what should have the greatest weight and value in life on the other. What ideals should we be educating children towards in a time in which everything is being relativised, including democratic principles themselves?

It is precisely the work of John Dewey that challenges us to develop an awareness of the connection between our thinking, which has to be developed through education, and the democratic ideal. To this day it is hard to find anyone who so comprehensively grasps the ethos of modernity, distinguished by hope in the success of a life philosophy based on a combination of critical spirit, respect for freedom and the human being and the will to action. For Dewey democracy is the search for the common shared meaning (Dewey, 2008, pp. 192-193) of community and an ideal that could genuinely affect individuals, making them aware of the meaning of the invested effort.

I believe that it is an error of our time to turn "education for democracy", like ethical education, into a special subject requiring its own special didactic methods as well as a curricular definition of goals and contents. Like ethics, democracy ought not to be a separate educational area, but should be the form of all educational activity. It was this that Dewey had in mind when in contrast to political science characterisations of democracy he defined it as a particular form of communal life, the political expressions of which may change.

It is a generally known thing that democracy is passionately devoted to education. The superficial explanation is that a government based on universal franchise cannot be successful if those who vote for, and who obey their governors, are not educated. Because democratic society rejects the principle of external power, it must find a substitute in readiness to volunteer and interest, and only education can instil these things. But there is an even deeper explanation. "A democracy is more than a form of government: it is primarily a mode of associated living, a conjoint communicated experience." (Dewey, 2008, p. 203, emphasis by M. S.)

We should note that Dewey refers to personal qualities like "readiness to volunteer" and "interest" - that is, attitudes without which no thinking, even the most self-critical, can be effective. If the barriers of class and culture that divide people are to be overcome, there needs to be a conjoint, communicated experience, and this is best provided by the school. But not the school of the past, which played a considerable role in building or strengthening those barriers. It must be a school where what has hitherto been 
separated will be presented as a comprehensive, mutually ninterconnected whole. This is a principle that can be applied both to social relations, where the goal is to lead the child to the ideal of human equality, and also to the curriculum, with the previously isolated subjects, each with its own material, being transformed into a comprehensive initiation into reality, which is ultimately one, even if it is manifested and perceived in many different ways.

\section{Conclusions}

We need to work educationally on changing the mode of thinking, where the criterion for success is achieving openness on all fronts; that means openness to natural and social reality, to history, to truth and most of all to my neighbour, who stands alongside me as a partner in the common striving for a good cause. It is doubtful whether these tasks can be fulfilled by the current conception of education for Democratic Citizenship as a crosscutting theme. Formally it probably could be, but not wholly, since it follows from the logic that cross-cutting themes do not relate to a separate subject. In practice, however, it is likely to form one. Yet democracy is a synonym for openness and cooperation, not an abstract doctrine without problems and antagonisms.

However, looking at the curriculum for teaching democratic citizenship and the recommendations relating to its revision we get a sense of unease. It becomes even worse as these recommendations rely on the Council of Europe documents which suggest that it is a much wider problem going beyond the Czech border. We come across the same "quasi-technical" vocabulary and approach as in the other areas of the curriculum in which the ideology of competences can be identified. As if democracy and a sense of democracy depended on training, situation modelling, the use of project-based and cooperative learning, possibly collaborative teaching and the ubiquitous use of modern technology (Vávrová \& Hesová et al., 2017, p. 17). However, live dialogue is not created by adding up the abstract categories of twenty competences, as the model in Competences for Democratic Culture suggests. Neither does the widespread conviction that ideas can be replaced by competences contribute to the understanding of the world as a dialogue in any way.

Moreover, democracy is also a battle. It is waged through gestures and words rather than violence, but manipulation and dogmatism may be implicit in symbolic violence too. Democracy must therefore be accompanied by attention to the word; it must be identified with the logocentric heritage 
of Europe and that heritage must be cultivated at the same time. Education is therefore the first essential component for maintaining a true democracy, for a democracy offered to uneducated, uncultivated people becomes very dangerous. This must be taken into account in what is known as education for democracy, and a high level of cultivation for every individual must be insisted upon.

The importance of classic works, a deep knowledge of history, and above all a developed ability for philosophical thought is what we should be transmitting, as well as a lively interest in practice. The current tendency to underestimate the importance of knowledge in favour of a so-called awareness of contexts and connections is false and dangerous. There is a need to teach contradictions - to show them in all their possible forms - using the examples of art and culture, past events, or quantum models. To get children used to the fact that throughout their lives they will be picking their way through these contradictions and that they will have to make responsible decisions about them. Democracy can hence be most effectively taught "in school" through various forms of thought and the interpretation of cultural heritage and the building of democratic relations within the framework of the school as an institution.

What should I say at the very end of this reflection? Perhaps that democracy is never a complete and accomplished thing, and it cannot mean one and the same thing forever. Its meaning and value will change - not of course, simply with regard to the personal interests of those involved, but always with regard to the needs of reality itself, in the light of whatever shows itself to be true and the right thing to do. Reality, after all, changes with every decision we make. It is we who change it. It is thus essential to react to these changes and integrate the results into further reflections on what we ought to do. Of course, at the risk of making mistakes. But only when our efforts are guided by our interest in the essential and truly human can we succeed in defending the ideal of democracy, and deepening and developing it.

\section{References}

Barrett, M. et al. (2016). Competences for democratic culture. Living together as equals in culturally diverse democratic societies. Strasbourg: Council of Europe Publishing. Brunschwicg, L. (1947). L'esprit européen. Neuchâtel: Éd. de la Baconnière.

Dewey, J. (1916/2008). Democracy and education. Project Guttenberg [EBook \#852]. Produced by David Reed, and David Widger. 
Finkielkraut, A. (1987). La défaite de la pensée. Paris: Gallimard.

Finkielkraut, A. (2015). La seule exactitude. Paris: Stock.

Foucault (1976/1997). Il faut défendre la société. Cours au Collège de France. Paris: Gallimard/Seuil.

Roberto Frega (2006). Pensée, expérience, pratique. Essai sur la théorie du jugement de John Dewey. Paris: L'Harmattan.

Hejdánek, L. (2012). Co je dnes zapotřebí. Praha: Sešity Knihovny Václava Havla č. 12 .

Jeřábek, T. et al. (2007). Framework educational programme for basic education. Praha: Výzkumný ústav pedagogický.

Kundera, M. (1990). L'immortalité. Paris: Gallimard.

Le Goff, J. (2003). Trop de droits tuent le droit. Ouest-France 25th September.

Lyotard, J.-F. (1979). La condition postmoderne. Paris: Éd. de Minuit.

Nussbaum, M. C. (2010). Not for profit. Why democracy needs the humanities. Princeton: Princeton University Press.

Patočka, J. (2002). Plato and Europe. Stanford University Press.

Plato. (1996). Ústava (The Republic). Praha: OIKOYMENH.

Popper, K. R. (1945). The open society and its enemies I, II. London: Routledge.

Quilliot, R. (1996). Culture et relativisme. Hermès, 1996(20), 239-250.

Steiner, G. (1990). Dans le château de Barbe-Bleue. Notes pour une redéfinition de la culture. Paris: Gallimard. [orig. Bluebeard's Castle: Some Notes Towards the Redefinition of Culture. Yale University Press, 1971.]

Vávrová, T., \& Hesová, A. et al. (2017). Výchova demokratického občana a Člověk $v$ demokratické společnosti jako průřezová témata. Podkladová studie. Praha: Národní ústav pro vzdělávání.

\section{Author}

Martin Strouhal, associate professor

Charles University

Faculty of Arts

Department of Education

Jan Palach 2 Square

Prague 1

11638

Czech Republic

Email: Martin.Strouhal@ff.cuni.cz 